\title{
Potensi dan Prospek Wisata Halal Dalam Meningkatkan Ekonomi Daerah (Studi Kasus: Nusa Tenggara Barat)
}

\author{
Alwafi Ridho Subarkah ${ }^{1}$ \\ alwafisubarkah@gmail.com
}

\begin{abstract}
Abstrak
Penelitian ini membahas tentang pariwisata halal sebagai instrumen diplomasi publik Indonesia untuk meningkatkan kunjungan wisatawan dan meningkatkan ekonomi daerah, karena potensi wisata halal yang besar diharapkan dapat memiliki pengaruh terhadap perekonomian daerah terutama bagi Provinsi Nusa Tenggara Barat sebagai destinasi wisata halal. Penelitian ini menggunakan penelitian kualitatif dengan pendekatan konsep diplomasi publik dan konsep pariwisata halal. Hasil penelitian ini menunjukkan bahwa diplomasi publik Indonesia dengan menampilkan diri sebagai destinasi wisata halal dianggap berhasil dapat menarik kunjungan wisatawan mancanegara terutama wisatawan Muslim dan menarik investasi, serta perkembangan wisata halal juga mengalami peningkatan yang positif, sehingga dengan meningkatnya kunjungan wisata dan investasi dapat dimanfaatkan untuk meningkatkan perekonomian daerah seperti Nusa Tenggara Barat sebagai destinasi wisata halal.
\end{abstract}

Kata Kunci: diplomasi publik, ekonomi daerah, Nusa Tenggara Barat, wisata halal

\begin{abstract}
This study discusses halal tourism as an instrument of Indonesian public diplomacy to increase tourist visits and improve regional economics, because large halal tourism potential is expected to have an influence on the regional economy, especially for West Nusa Tenggara Province as a halal tourist destination. This study uses qualitative research with the concept of public diplomacy and halal tourism concepts. The results of this study indicate that Indonesian public diplomacy by presenting itself as a halal tourist destination is considered successful can attract foreign tourists, especially Muslim tourists and attract investment, as well as the development of halal tourism also has a positive increase, so that increased tourist visits and investments can be used to improve the economy areas such as West Nusa Tenggara as halal tourist destinations.
\end{abstract}

Keywords: Halal tourism, public diplomacy, local economy, West Nusa Tenggara

\section{Pendahuluan}

Pariwisata merupakan sektor untuk menumbuhkan perekonomian dunia yang sangat menjanjikan karena sektor pariwisata juga menjadi sektor yang tahan terhadap krisis global dilihat dari perkembangan perjalanan wisata dunia yang mengalami perkembangan positif sejak tahun 1950 jumlah perjalanan wisata 25 juta orang, tahun 1980 mencapai 278 juta orang, 1995 mencapai 528 juta orang, dan 1,1 miliar orang pada tahun 2014. (Ratman, 2016:4). Selain itu, kasus global seperti

\footnotetext{
${ }^{1}$ Korespondensi: Mahasiswa Program Magister Hubungan Internasional, Fakultas Ilmu Sosial dan Politik, Universitas Padjadjaran.
} 
terorisme, virus Ebola, virus Zika pada tahun 2014 yang berlanjut hingga 2015 juga mempengaruhi pertumbuhan pariwisata namun dapat menuju yang lebih baik, mencapai 4,4 persen dengan jumlah perjalanan wisata mencapai 1,184 wisatawan pada tahun 2015, beberapa faktor seperti keselamatan dan keamanan mempengaruhi wisatawan untuk melakukan perjalanan, selain itu faktor yang mempengaruhi terhadap pariwisata yaitu fluktuasi nilai mata uang, harga minyak mentah dunia menurun, serta harga komoditas internasional yang juga menurun. Namun, kawasan Eropa yang menurun nilai tukar mata uang terhadap dolar Amerika Serikat justru kawasan tersebut menjadi paling banyak yang mendatangkan wisatawan, dengan capaian 609 juta orang dari 1,2 miliar wisatawan dunia pada tahun 2015. Lalu, Perancis menjadi negara yang mendatangkan wisatawan terbanyak meski adanya terorisme pada November 2015, pada tahun tersebut dapat menarik kunjungan wisatawan dunia 86,3 juta, sedangkan tahun 2014 mencapai 83,8 juta wisatawan. Sedangkan menguatnya mata uang AS dapat menjadikan stimulus bagi wisatawan asal AS untuk melakukan perjalanan wisata. (Sucipto, 2016).

Sedangkan pariwisata Indonesia yang pertumbuhan sektor wisatanya tercepat dan menjadi sektor ekonomi terbesar karena kontribusi terhadap devisa negara terbesar kedua setelah industri kelapa sawit yang mencapai USD 15.965 Miliar pada tahun 2016 sedangkan pariwisata menduduki kedua mencapai USD 13.568 Miliar pada tahun 2016, sedangkan pada tahun 2015 sektor pariwisata berada di posisi keempat yang memberikan kontribusi terhadap devisa dengan capaian USD 12.225 Miliar di bawah Minyak dan Gas (USD 18.574 Miliar), Kelapa Sawit (USD 16.427 Miliar), Batu Bara (USD 14.717 Miliar) (Chandra \& Damarjati, 2017).

Hal ini juga menjadikannya sektor unggulan karena beberapa hal, yaitu: jumlah destinasi dan investasi pariwisata yang meningkat menjadikannya faktor kunci dalam menciptakan lapangan kerja, infrastruktur, pengembangan usaha, hingga pendapatan dari ekspor. Indonesia memproyeksikan pada tahun 2019 sektor ini dapat meningkatkan Produk Domestik Bruto (PDB) sebesar 15 persen, dengan kunjungan 20 juta wisatawan mancanegara, 275 juta perjalanan yang dilakukan wisatawan nusantara, dan diharapkan mampu menyerap tenaga kerja hingga 13 juta. (Susanti, 2017). 
Untuk menyambut potensi wisata tersebut, Indonesia menjadikan pariwisata sebagai sektor utama dalam pembangunan nasional selain pertanian/perkebunan, minyak dan gas, serta pertambangan, seperti membuat perencanaan pembangunan pariwisata tahun 2015-2019. Pada tahun 2014 jumlah kunjungan wisatawan mancanegara mencapai 9 juta orang, dan diharapkan pada tahun 2019 mencapai 20 juta orang, sedangkan wisatawan domestik melakukan perjalanan wisata yang pada tahun 2014 mencapai 250 juta orang, diharapkan pada tahun 2019 mencapai 275 juta orang, dengan harapan mempengaruhi pertumbuhan Produk Domestik Bruto (PDB) nasional pada tahun 2014 mencapai 4,2\%, diharapkan pada tahun 2019 mencapai 8\%. Selain itu diharapkan pada tahun 2019 memberikan kontribusi bagi devisa mencapai Rp. 240 triliun sedangkan pada tahun 2014 hanya mencapai Rp. 120 triliun. Sehingga diharapkan pertumbuhan secara inklusif dapat meningkatkan usaha lokal dalam bidang pariwisata dan tenaga kerja yang tersertifikasi. (Deputi Bidang Ekonomi, 2014:2).

Dalam mewujudkan sasaran pembangunan tersebut, dilakukan berbagai upaya pembangunan pariwisata, sektor ini memiliki perkembangan dalam segmentasinya, saat ini yang cukup pesat perkembangannya dan menjadi trend di dunia internasional adalah pembangunan wisata halal. Segmen wisata yang memberikan pelayanan terhadap wisatawan Muslim yang ingin melakukan perjalanan wisata sesuai dengan prinsip-prinsip Islam, sehingga wisatawan Muslim menjadi merasa lebih nyaman dan aman dalam menikmati perjalanan wisata, serta dapat melaksanakan kewajibannya sebagai seorang Muslim sesuai dengan ajaran Islam seperti wajib mengkonsumsi makanan dan minuman halal, melaksanakan solat fardu di tempat yang representatif, dan tempat tinggal yang terhindar dari maksiat dengan adanya hotel syariah.

Seperti dalam jurnal Intermestik, penelitian dengan judul Diplomasi Pariwisata Halal Nusa Tenggara Barat dalam penelitian tersebut menjelaskan pariwisata halal menjadi instrumen dalam melakukan diplomasi publik yang dapat meningkatkan kunjungan wisatawan ke Nusa Tenggara Barat. (Subarkah, 2018:188-203). Penelitian Aan Jaelani, dengan judul Halal Tourism Industry in Indonesia: Potential and Prospect dengan hasil penelitian bahwa Indonesia dengan mayoritas Muslim dengan mudah mengembangkan wisata halal dan dapat menjadi kiblat dunia dalam wisata halal 
(Jaelani, 2017:23-34). Ada juga penelitian dari Intan Komalasari yang berjudul Upaya Indonesia Meningkatkan Daya Saing Muslim Friendly Tourism (MFT) Diantara Negara-Negara OKI dengan hasil penelitian bahwa Indonesia menujukkan komitmen dalam pembangunan wisata yang ramah terhadap wisatawan Muslim dengan mengalokasikan anggaran secara khusus untuk pembangunan wisata halal, melakukan beberapa standarisasi sesuai berdasar pada kesepakatan negara-negara anggota Organisasi Kerjasama Islam, serta membuat konferensi untuk memperkenalkan konsep wisata halal (Komalasari, 2017:1-12). Dari ketiga penelitian tersebut menunjukkan adanya potensi yang positif bagi daerah yang ingin mengembangkan wisata halal yang didefinisikan sebagai segmen wisata berdasarkan ajaran-ajaran Islam namun tidak menutup kemungkinan dapat diperuntukkan bagi wisatawan non Muslim, segmen wisata ini dianggap potensial dengan harapan dapat meningkatkan kunjungan wisata serta meningkatkan perekonomian.

Sehingga penelitian ini akan membahas kebijakan luar negeri Indonesia dalam menggunakan potensi wisata halal yang dijadikan sebagai instrumen diplomasi publik demi mencapai kepentingan nasional untuk menarik kunjungan wisata, investasi, dan membangun citra sebagai negara yang ramah terhadap wisatawan Muslim, terutama wisatawan yang berasal dari kawasan Timur Tengah sebagai target pasar utama.

\section{Tinjauan Pustaka}

Ada dua konsep yang dapat menjelaskan tentang fenomena yang diteliti, yaitu diplomasi publik sebagai upaya untuk menampilkan diri di dunia internasional agar menarik wisatawan dan investasi, dan konsep pariwisata halal sebagai upaya untuk menciptakan iklim wisata ramah terhadap wisatawan Muslim yang sesuai dengan nilainilai dan ajaran Islam.

\section{Diplomasi publik}

Diplomasi publik adalah cara suatu negara untuk menampilkan diri di pentas internasional dengan tujuan memberikan informasi atau pengetahuan terkait negara tersebut kepada publik melalui berbagai media. Namun, aktor dari diplomasi publik tidak hanya negara atau bersifat state-sentris, pemerintah daerah atau sub-state dapat melaksanakan diplomasi publik (Indraswari \& Hermawan, 2015:4-5). Sedangkan 
Tony Dian Effendi (2013:53) menjelaskan perbedaan antara diplomasi publik dan diplomasi tradisional dilihat dari target yang dituju oleh pelaku diplomasi, diplomasi publik dapat menjadikan individu, perusahaan multinasional, serta aktor non-negara lainnya sebagai sasaran dan aktor dalam melakukan diplomasi dan diplomasi tradisional lebih kepada hubungan antar negara sebagai aktor dan target diplomasi.

Lebih lanjut, Effendi menjelaskan ada empat bagian dalam upaya melakukan diplomasi publik, yaitu: introducting, yaitu upaya memperkenalkan dapat melalui pameran, atau mengikuti event internasional; increasing a positives appreciation, dapat dilakukan untuk memenuhi pelayanan dan fasilitas; engaging, yaitu meningkatkan rasa keterkaitan dengan wisatawan dengan melakukan familiarization trip untuk mengenalkan wisata dan budaya; influencing, agar dapat meningkatkan kerjasama dalam bidang pariwisata (Effendi, 2011). Diplomasi publik dapat dijadikan alternatif bagi negara agar lebih menarik dalam menampilkan diri di dunia internasional dengan melibatkan publik demi terciptanya hubungan yang baik antar negara.

Salah satu unsur dari diplomasi publik adalah diplomasi budaya karena dalam diplomasi kebudayaan tersebut terjadi pertukaran ide, informasi, dan aspek budaya lainnya mewakili ide atau gagasan dari suatu negara sehingga terjadi saling pengertian antar negara. (U.S. Departement of State, 2015:4). Unsur dari diplomasi budaya sebagai instrumen dari diplomasi publik salah satunya pariwisata, karena melalui kegiatan wisata terjadi interaksi budaya yang membuat orang menjadi lebih dekat dan paham tentang negara itu sendiri, dan pariwisata merupakan diplomasi publik yang dapat menggerakkan sektor sektor-sektor ekonomi. (Turkish Asian Center For Strategic Studies, 2016). Hal ini menjadikan diplomasi publik sebagai upaya yang lebih soft dalam menjalin hubungan sesama negara untuk mencapai tujuannya, hal ini menggunakan pariwisata untuk mencapai tujuan sektor ekonomi dengan meningkatkan kunjungan wisata.

Ada pun beberapa hal yang dapat dicapai oleh diplomasi publik, yaitu: masyarakat lebih mengetahui tentang suatu negara, persepsi terhadap negara tersebut melalui pembangunan image positif dapat mengubah opini publik terhadap suatu negara. Masyarakat domestik dapat terlibat langsung dalam membangun citra yang baik sehingga masyarakat internasional tertarik untuk berkunjung. (Leonard, Stead, \& Smewing, 2002:9-10). Media dalam diplomasi publik yaitu dapat melalui televisi, radio, 
film, musik, culture, dan yang lain-lain. Saat ini lebih luas lagi karena aktor diplomasi publik pun bisa individu, sosial media menjadi alat yang cukup baik untuk melakukan diplomasi publik, karena sosial media menjangkau berbagai kalangan, dari berbagai daerah serta dapat dengan cepat sampai kepada target. (Ayad, 2012: 23-32).

Dalam konteks penelitian ini diplomasi publik dengan membangun wisata halal dilakukan oleh pemerintah daerah Nusa Tenggara Barat sebagai representasi Indonesia dalam menampilkan diri sebagai negara yang ramah terhadap wisatawan Muslim terutama kepada wisatawan yang berasal dari kawasan Timur Tengah, maupun wisatawan Muslim dari berbagai belahan dunia lainnya, sehingga destinasi wisata halal ini diharapkan mampu tidak hanya menarik kunjungan wisatawan Muslim, tetapi juga menarik investasi untuk meningkatkan ekonomi daerah menuju arah yang positif.

\section{Konsep Pariwisata Halal}

Organisasi Konferensi Islam (OKI) memberikan definisi wisata halal, terminologi yang digunakan OKI adalah Islamic Tourism yaitu Islam dan pariwisata didasari pada Al-Qur'an 29:20 yang menganjurkan manusia untuk melakukan perjalanan di bumi untuk mengambil pelajaran dari ciptaan Allah dan mengambil rahmat-Nya. Islamic Tourism didefinisikan sebagai perjalanan wisata yang ditujukan untuk memberikan pelayanan dan fasilitas wisata bagi wisatawan Muslim sesuai dengan kaidah Islam. Adapun beberapa istilah yang digunakan selain Islamic Tourism, yaitu Halal Tourism, Syariah Tourism, Muslim-Friendly Tourism. (Organisasi Kerjasama Islam, 2017: 4). Peneliti di sini lebih memilih menggunakan wisata halal atau halal tourism karena kata tersebut lebih mewakili aspek wisata yang ramah terhadap wisatawan Muslim dan juga mewakili syariah Islam dengan kata 'Halal' yang tidak sekedar mewakili makanan dan minuman, tetapi juga hotel, fasilitas, dan pelayanan sesuai dengan syariat Islam.

Sedangkan Global Muslim Travel Index (Global Muslim Travel Index, 2016:7) sebagai lembaga yang berfokus pada pengembangan wisata halal dunia menjelaskan bahwa wisata halal adalah pariwisata yang dijalankan sesuai dengan prinsip-prinsip Islam dengan tujuan memberikan fasilitas dan layanan yang ramah terhadap wisatawan Muslim. Beberapa hal yang perlu diperhatikan dalam wisata halal, yaitu: pemerintah daerah dapat memenuhi layanan ibadah seperti fasilitas solat; lalu tersedianya makanan dan jaminan dengan label halal, fasilitas umum yang memadai 
seperti toilet dengan air bersih, layanan maupun fasilitas saat bulan Ramadhan, serta tidak adanya aktivitas minuman beralkohol dan layanan private yang dapat membedakan antara perempuan dan laki-laki.

Indonesia sendiri dalam mengembangkan wisata halal mengadopsi dari kriteria Global Muslim Travel Index sebagai acuan pembangunan wisata halal. (Pratiwi, 2016). Untuk itu dibentuk suatu badan dibawah naungan Kementerian Pariwisata Republik Indonesia yang memiliki kewenangan dan tanggung jawab dalam mengatur pariwisata di Indonesia, badan khusus bernama Tim Percepatan Pembangunan Pariwisata Halal (TP3H) suatu tim yang diberikan kewenangan dalam membantu pemerintah memetakan, mengembangkan dan memberikan pedoman daerah yang memiliki potensi untuk mengembangkan wisata halal, tim ini kemudian membentuk tiga kriteria umum dalam mengembangkan wisata halal, seperti yang tertera pada Tabel 1.

\section{Tabel 1. Kriteria Umum Pariwisata Halal}

\begin{tabular}{c|l} 
Kategori & \multicolumn{1}{c}{ Indikator } \\
\hline $\begin{array}{c}\text { Destinasi } \\
\text { Pariwisata (Alam, }\end{array}$ Budaya, Buatan) & $\begin{array}{l}\text { Tersedia pilihan aktivitas wisata, seni, dan budaya yang tidak } \\
\text { mengarah pada pornoaksi, dan kemusyrikan }\end{array}$ \\
\cline { 2 - 2 } & $\begin{array}{l}\text { Bila memungkinkan menyelenggarakan minimal satu festival balal life } \\
\text { style }\end{array}$ \\
\cline { 2 - 3 } & Pramuwisata berpakaian dan berpenampilan sopan \\
\cline { 2 - 3 } & $\begin{array}{l}\text { Tersedia pilihan daya tarik wisata pantai dan pemandian yang } \\
\text { terpisah untuk pria dan wanita dan/atau mempunyai aturan } \\
\text { pengunjung tidak berpakaian minim }\end{array}$ \\
\hline \multirow{5}{*}{ Hotel } & Tersedia makanan halal \\
\cline { 2 - 3 } & $\begin{array}{l}\text { Tersedia fasilitas yang memudahkan untuk beribadah, seperti Masjid, } \\
\text { Mushola dan fasilitas bersuci }\end{array}$ \\
\cline { 2 - 3 } & $\begin{array}{l}\text { Tersedia playanan saat bulan Ramadhan untuk memenuhi kebutuhan } \\
\text { sahur dan buka puasa }\end{array}$ \\
\cline { 2 - 3 } & $\begin{array}{l}\text { Tidak adanya aktivitas non-halal seperti perjudian, minuman } \\
\text { beralkhohol, dan kegiatan diskotik }\end{array}$ \\
\cline { 2 - 3 } & $\begin{array}{l}\text { Tersedia fasilitas rekreasi kolam reang dan fasilitas kebugaran/gym } \\
\text { yang terpisah antara pria dan wanita }\end{array}$ \\
\cline { 2 - 3 } & $\begin{array}{l}\text { Bila hotel menyediakan fasilitas spa, maka terapis pria untuk } \\
\text { pelanggan pria dan terapis wanita untuk pelanggan wanita. Terapi } \\
\text { tidak menggunakan bahan yang mengandung babi, alkholol maupun } \\
\text { produk turunannya }\end{array}$ \\
\hline Biro Perjalanan & $\begin{array}{l}\text { Menyediakan paket wisata yang sesuai dengan kriteria umum } \\
\text { Pariwisata Halal }\end{array}$ \\
\cline { 2 - 3 } & Tidak menawarkan aktivitas non-halal \\
\cline { 2 - 3 } Memiliki daftar usaha penyedia makanan dan minuman halal
\end{tabular}




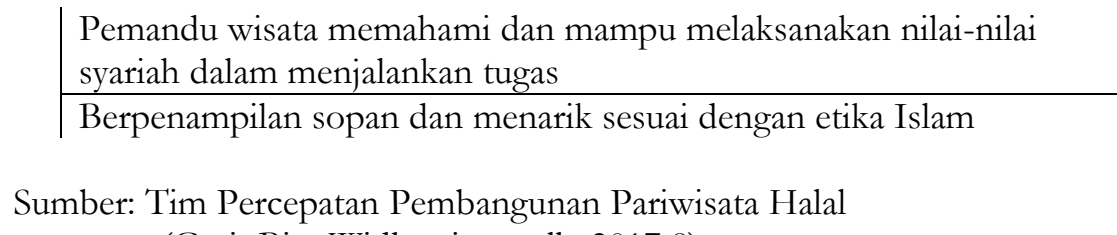

(Garit Bira Widhasti., et. all., 2017:8)

Dijelaskan juga sebelumnya dalam tulisan Demeiati Nur Kusumaningrum dkk (2017) di mana, konsep wisata halal dipahami sebagai nilai-nilai ajaran Islam yang diimplemetasikan sebagai landasan dalam melakukan perjalanan wisata tanpa mendiskriminasikan wisatawan non-muslim. Wisata halal ini dijadikan sebagai soft power untuk menarik kunjungan wisatawan Muslim. (Kusumaningrum, Fairuz, Putri, \& Amalia, 2017). Sedangkan (Battour \& Ismail, 2015) melihat wisata halal adalah setiap objek dan perilaku wisata yang melibatkan orang Muslim dengan menggunakan ajaranajaran Islam sebagai pedoman dalam industri pariwisata. Noriah Ramli juga menjelaskan bahwa wisata halal sebagai suatu perjalanan wisata yang memiliki pelayanan sesuai dengan syariah Islam, juga sebagai wisata pilihan bagi wisatawan Muslim untuk menghindari wisata konvensional yang ada menyediakan minuman beralkohol, makanan dengan unsur babi, dan tempat wisata yang tidak memisahkan antara pria dan wanita. (Ramli, 2012:2-3)

Dapat diambil kesimpulan istilah wisata halal, yaitu wisata yang ingin memberikan layanan dan fasilitas wisata kepada wisatawan Muslim yang juga dapat dinikmati oleh wisatawan non-Muslim, di mana setidaknya memenuhi tiga kebutuhan dasar dalam wisatawan Muslim, yaitu: adanya fasilitas dan layanan ibadah yang memadai, tempat tinggal yang ramah terhadap wisatawan Muslim (hotel syariah), makanan dan minuman dengan jaminan halal melalui sertifikasi badan tertentu yang memiliki kewenangan untuk melakukan itu, serta destinasi wisata seperti wisata alam, budaya, wisata buatan yang dilengkapi dengan fasilitas atau infrastruktur untuk ibadah, seperti adanya masjid atau musholla di sekitar tempat wisata.

\section{Metode}

Penelitian ini menggunakan metode kualitatif dengan sifat deduktif yang menjelaskan kebijakan Indonesia menjadikan wisata halal sebagai instrumen mencapai kepentingan nasional dalam hal ekonomi dan kunjungan wisata melalui citra positif 
sebagai negara yang tamah terhadap wisata halal. Unit analisisnya yaitu konsep wisata halal Indonesia dan untuk menjelaskan potensi pasar wisata halal dunia dan potensi wisata halal yang dimiliki oleh Nusa Tenggara Barat sebagai instrumen diplomasi publik, unit eksplanasi yaitu menjelaskan kepentingan negara dipengaruhi oleh faktor internal yaitu domestik yang memiliki potensi untuk mengembangkan wisata halal, serta faktor eksternal yaitu potensi wisata halal dan wisatawan Muslim yang terus mengalami perkembangan. Pengumpulan data diperoleh melalui studi pustaka, yaitu observasi literatur dari berbagai sumber seperti laporan, buku, jurnal, hasil wawancara kepada Dinas Pariwisata Nusa Tenggara Barat sebagai data primer, dan artikel maupun berita yang sesuai untuk mendukung penelitian terkait pariwisata halal dan upaya pemerintah Nusa Tenggara Barat dalam membangun pariwisata halal sebagai representasi Indonesia dalam melakukan diplomasi publik

\section{Hasil dan Pembahasan}

\section{Hubungan Antara Pariwisata Sebagai Alternatif Pembangunan Ekonomi}

Kebijakan luar negeri dengan melakukan diplomasi publik melalui pembangunan wisata halal tentunya secara rasional ingin memenuhi kepentingan nasional, dalam hal ini adalah mencapai kepentingan dalam bidang ekonomi dengan menarik kunjungan wisatawan Muslim sebagai target pasar utama. Pariwisata dan ekonomi memiliki keterkaitan yang kuat, seiring berkembangnya pariwisata di suatu daerah sangat memungkinkan untuk berkembangnya perekonomian di daerah tersebut. Hubungan keduanya saling melengkapi, ekonomi akan tumbuh jika ditopang oleh perkembangan wisata yang semakin maju, terutama bagi pelaku usaha sekitar destinasi wisata, baik pelaku usaha kecil, menengah, maupun yang besar. Menurut Cooper (2005) dalam (Remi, Waluyo, \& Muljarijadi, 2016:4-5) model ekonomi pariwisata ada tiga unsur yang terkait, yaitu: 1) konsumen dalam hal ini adalah wisatawan; 2) mata uang yang beredar sebagai unsur dalam transaksi ekonomi; 3) adanya barang dan jasa dari sektor ekonomi.

Hipotesis menarik yang dikemukakan oleh Muhammad Afdi Nizar tentang hubungan antara pariwisata dan ekonomi yang kausalitas, yakni: a) pertumbuhan ekonomi ditopang oleh pariwisata, maka dari itu pertumbuhan ekonomi 
dipengaruhi oleh perkembangan pariwisata (tourism-led economic growth hypothesis); b) pariwisata ditopang oleh ekonomi, sehingga perkembangan wisata dipengaruhi oleh pertumbuhan ekonomi (economic-driven tourism hypothesis); c) keduanya (ekonomi dan pariwisata) memiliki manfaat satu sama lain dan bersifat dua arah (reciprocal causal bypothesis). Lalu, Nizar berpendapat bahwa ada dua hal yang membangun adanya hubungan antara pariwisata dan ekonomi, yakni: 1) pariwisata berdampak pada ekonomi karena dapat menciptakan lapangan kerja, berpengaruh terhadap pendapatan, neraca pembayaran, penerimaan devisa dari beberapa hal, seperti belanja wisatawan, pembangunan pariwisata, impor maupun ekspor barang dan lain-lain; 2) pariwisata dapat menjadi efek stimulus bagi produk-produk tertentu dan dapat membentuk komunitas-komunitas yang diharapkan hal tersebut dapat menggerakkan ekonomi daerah ke arah yang positif dengan diciptakannya lapangan kerja baru dan meningkatnya pendapatan bagi daerah. (Nizar, 2011: 7-8).

Menurut Cohen (1984) dalam (Aryunda, 2011: 3) bahwa dampak pariwisata terhadap ekonomi dapat secara umum, yakni dapat menjadi sumber devisa, sumber penghasilan masyarakat, pendapatan bagi pemerintah, tercipta lapangan kerja, pengaruh terhadap harga dan tarif, pengaruh pada distribusi keuntungan maupun manfaat, pengaruh terhadap pengelolaan maupun kepemilikan, dan tentunya dapat mempengaruhi pembangunan. Ada beberapa hal yang dapat mempengaruhi penghasilan terkait pariwisata, diantaranya tingkat konsumsi atau pengeluaran, jarak dari tempat wisata, masa kerja dan jumlah wisatawan yang berkunjung. (Hairey, 2013:98).

Sedangkan Dian Dinta Herlambang berpendapat setidaknya ada empat hal yang dapat dipengaruhi oleh pariwisata terhadap kondisi ekonomi di tempat wisata, yakni: a) jenis pekerjaan, masyarakat menjadi memiliki pekerjaan, seperti pedagang asongan, lalu menjadi pegawai di tempat wisata (penjual tiket masuk, pengawas keamanan, pengelola sampah dan lain-lain); b) pendapatan masyarakat juga tentunya akan merasakan dampak dari pembangunan pariwisata; c) tumbuhnya sektor lain di sekitar tempat wisata, berdirinya warung-warung, ada penginapan yang dimiliki dan dikelola oleh masyarakat sekitar; d) di tempat wisata juga makanan maupun minumn akan mengalami perubahan harga yang dapat menjadi keuntungan bagi pedagang. (Herlambang, 2016: 14-15). Menurut (Sukadijo, 1997:25) pengaruh pembangunan 
pariwisata terhadap perekonomian dapat mengubah beberapa hal, yakni: berubahnya jenis pekerjaan, pendapatan masyarakat, pembagian kerja, serta kesempatan kerja maupun wirausaha. (Aryani, Sunarti, \& Darmawan, 2017).

Secara garis besar, pariwisata memiliki peran penting dalam meningkatkan sektor ekonomi, usaha lokal akan tumbuh, pekerjaan dapat tercipta, pendapatan juga beragam, hal ini yang menjadikan bahwa pariwisata sangat berdampak terhadap ekonomi suatu daerah. Jadi, ekonomi dan pariwisata memiliki keterkaitan yang sangat kuat dan saling satu dengan yang lainnya. Pariwisata dapat dijadikan sebagai penggerak ekonomi daerah wisata yang tahan terhadap krisis ekonomi, mudah dan murah untuk dikembangkan, serta ekonomi menjadi unsur dalam membantu perkembangan wisata, terutama wisata halal diharapkan mampu sebagai tonggak perekonomian daerah Nusa Tenggara Barat dengan potensi wisata halal dunia yang terus mengalami peningkatan sebagai alternatif penggerak perekonomian dengan meningkatkan kunjungan wisata dan investasi ke NTB yang menjadikan Timur Tengah sebagai target pasar wisata.

\section{Potensi Wisata Halal Dunia dan Pasar Wisatawan Timur Tengah}

Wisata halal menjadi tren baru dalam segmen pariwisata dunia, perkembangannya pun terus mengalami peningkatan. Terlihat sejak tahun 2014 ada 108 juta wisatawan muslim yang melakukan perjalanan wisata, meningkat di tahun 2015 yang mencapai 117 juta wisatawan muslim, lalu tahun 2016 mencapai 121 juta wisatawan muslim, dan juga mengalami peningkatan di tahun 2017 hingga 131 juta wisatawan muslim. Nilai perjalanan wisatawan Muslim secara global diproyeksikan mengalami peningkatan dari tahun 2014 mencapai nilai USD 145 Miliar, dan di tahun 2026 akan mencapai USD 300 Miliar (Global Muslim Travel Index, 2015, 2016, 2017, 2018).

Ada beberapa hal yang membuat segmen ini mengalami pertumbuhan yang cukup signifikan, yaitu: pertumbuhan populasi Muslim yang paling cepat mengalami peningkatan, pertumbuhan middle class income dari populasi Muslim yang cukup besar, populasi Muslim dengan usia rata-rata 24 tahun pada tahun 2015 juga menjadi peluang karena usia muda ini yang sering melakukan perjalanan wisata, meningkatnya akses informasi dengan berbagai media yang menjadikannya cepat diketahui oleh masyarakat luas, fasilitas dan pelayanan yang ramah terhadap wisatawan 
Muslim juga meningkat, Ramadan Travel yakni adanya layanan pada bulan Ramadan membuat wisatawan Muslim tertarik untuk berkunjung, dan bisnis travel yang semakin beragam dengan cepat menangkap peluang untuk melayani wisatawan Muslim. (Global Muslim Travel Index, 2018).

Bagi Indonesia hal ini menjadi peluang untuk meningkatkan pertumbuhan ekonomi dengan jumlah wisatawan Muslim dengan target pasar wisatawan yang berasal dari kawasan Timur Tengah, seperti Arab Saudi dan Mesir pada tahun 2017 yang datang berjumlah 222.362 wisatawan dengan rata-rata lama tinggal di Indonesia bagi wisatawan asal Arab Saudi 10,83 hari menghabiskan USD 2.226 untuk satu orang, sedangkan Mesir 10,47 hari yang menghabiskan USD 1.293 untuk satu orang. Karakteristik dari wisatawan asal Timur Tengah ini yaitu wisatawan yang lebih menyukai jenis wisata leisure, maka dari itu mereka berkunjung ke Lombok, Nusa Tenggara Barat, Sumatera Barat (Rosana, 2018).

\section{Wisatawan Muslim Millennial}

Target pasar wisata halal yang tumbuh pesat adalah Wisatawan Muslim Millennial yang menggerakan pertumbuhan pasar wisata halal. Secara populasi, usia rata-rata Muslim pada tahun 2010 berada di usia 23 tahun. Wisatawan Muslim Millennial ini yang disebut juga dengan generasi $\mathrm{Y}$ yang dalam rentan usia 20 tahun hingga 38 tahun memiliki potensi sebagai segmen konsumen yang tumbuhnya paling cepat, mewakili 20\% wisatawan internasional. Pada tahun 2020, Generasi Millennial diharapkan untuk melakukan 320 juta perjalanan internasional setiap tahunnya, mewakili kenaikan 47\% yang luar biasa dari 217 juta pada tahun 2013 (Mastercard \& Halal Trip, 2017: 4).

Wisatawan millennial pada umumnya adalah kelompok yang unik dengan kebutuhan, karakter, motif dan harapan khusus. Tidak seperti generasi sebelumnya, Milenium adalah penduduk asli digital dan sering berbagi pengalaman dan pendapat mereka secara terbuka di internet, khususnya di situs media sosial. Memiliki akses yang lebih besar terhadap pendidikan dan informasi, segmen pasar ini sering menempatkan lebih banyak waktu dan usaha untuk melakukan penelitian komprehensif sebelum membuat jadwal perjalanan. Ada 3A yang mempengaruhi keputusan mereka dalam melakukan perjalanan wisata - Authentic: Destination discovery, Local cuisine, Flexible 
itinerary; Affordable: Accommodation, Transport, Experiences; Accessible: Technology, Information, Sharing. 3A merangkum pola perjalanan utama di seluruh pengalaman perjalanan wisatawan Muslim millennial dari perencanaan perjalanan hingga berbagi pengalaman dengan orang lain. Karena internet dan lingkungan sosial memainkan peran kunci dalam kehidupan sehari-hari, tujuan dan penyedia layanan pariwisata harus mengembangkan penawaran yang selaras dengan 3As untuk melengkapi fasilitas mereka ke segmen wisata halal ini. (Mastercard \& HalalTrip, 2017: 5-6).

Wisatawan Muslim millennial ini menghabiskan waktu liburan dalam satu tahun dapat melakukan wisata dua kali hingga lima kali, dan menghabiskan waktu empat hingga enam hari untuk melakukan sekali kunjungan wisata. Segmen pasar Millennial sangat menghargai perjalanan sebagai gaya hidup dan pengalaman hidup, dan perjalanan untuk berbagai alasan. Hasil survei menunjukkan bahwa ada tiga hal utama yang menjadi tujuan perjalanan yang paling menonjol wisatawan Muslim millennial melakukan kegiatan wisata, yaitu: (1) leisure and holiday, (2) experiencing local culture and heritage, and (3) visiting friends and relatives. Perjalanan lebih dari sekadar liburan bagi wisatawan ini, sering dilakukan untuk pertumbuhan atau perkembangan pribadi, untuk mencari pengalaman baru dan untuk ikatan sosial karena dapat bertemu dengan orang-orang baru yang memiliki sosial dan budaya yang berbeda. (Mastercard \& Halal Trip, 2017: 19).

Dalam melakukan perjalanan wisata, segmen wisatawan ini memperhatikan biaya perjalanan, biaya yang dikeluarkan adalah USD 101 hingga USD 500, biaya ini tergolong kecil karena wisatawan Muslim Millennial ini sebagaian besar terdiri dari anak sekolah atau mahasiswa, anak-anak yang baru lulus sekolah atau kuliah, karyawan baru, yang memiliki biaya terbatas, sehingga biaya sangat penting dalam merencanakan kegiatan wisata. Wisatawan Muslim Millennial ini menghabiskan biaya setidaknya untuk lima hal, penerbangan, akomodasi, makanan, belanja, dan aneka barang -misalnya tiket masuk, tempat wisata, transportasi lokal, dll (Mastercard \& Halal Trip, 2017: 20).

Wisatawan Muslim Millennial ini melakukan kegiatan wisata lebih banyak bersama keluarga dan teman, ditunjukkan untuk lebih meningkatkan ikatan sosial antar mereka, selain itu ada juga yang melakukan kegiatan wisata sendiri, ini merepresentasikan wisatawan millennial merupakan wisatawan yang mandiri dan 
pemberani. (Mastercard \& Halal Trip, 2017: 21). Ada beberapa hal yang dapat mempengaruhi keputusan wisatawan Muslim Millennial dalam menentukan perjalanan wisata, yaitu: biaya penerbangan dan penginapan; masalah keamanan dan terorisme; ketersediaan makanan halal; pengalaman baru/menarik; ketersediaan atraksi wisata; keramahan orang lokal; sentimen islamophobia; cuaca; fasilitas ramah Muslim; hiburan dan perbelanjaan; durasi penerbangan (Mastercard \& Halal Trip, 2017: 23).

Wisatawan Muslim Millennial dapat menjadi target dalam menarik kunjungan wisata halal di Nusa Tenggara Barat, mereka dengan karakteristik yang sedemikian rupa dapat menjadi target potensial, dan Nusa Tenggara Barat dapat memenuhi kebutuhan jenis wisatawan ini, karena NTB memiliki destinasi, fasilitas, dan layanan wisata halal terbaik yang menjadikan NTB sebagai destinasi wisata halal terbaik dunia dalam ajang wisata halal dunia pada tahun 2015 dan 2016 di Abu Dhabi.

\section{Wisata Halal Sebagai Diplomasi Publik Indonesia \\ a. Introducting Dengan Mengikuti Event Internasional}

Upaya pertama dalam melakukan diplomasi publik yaitu memperkenalkan diri, dalam hal ini melalui kegiatan internasional seperti pameran, table top atau event internasional lainnya. Indonesia memperkenalkan diri di Timur Tengah sebagai wisata halal dengan mengikuti kegiatan World Halal Travel Awards 2015 suatu kegiatan internasional yang memberikan penghargaan bagi pelaku wisata halal di dunia, acara tersebut berlangsung di Abu Dhabi, 20 Oktober 2015, Indonesia berhasil meraih penghargaan pada tiga kategori, yaitu: World's Best Halal Tourism Destination untuk Lombok; World's Best Halal Honeymoon Destination untuk Lombok; dan World's Best Family Friendly Hotel untuk Sofyan Hotel Betawi, Jakarta. (World Halal Travel Summit, 2015).

Pada tahun 2016 Indonesia kembali meraih penghargaan dalam acara World Halal Tourism Award 2016 yang diumumkan di Abu Dhabi pada 7 Desember 2016 meraih 12 penghargaan hasil dari pemilihan sejumlah 1,9 juta pemilih dari 116 negara. (Indonesia.Travel, 2018). Selain itu, Indonesia memperkenalkan diri dalam acara Jeddah International Tourism and Travel Exhibition (JITTE) merupakan bursa pameran pariwisata terbesar berlangsung di Arab Sudi pada 28 Februari hingga Maret 2018. (Aprilyani, 2018). Hal ini menambah nilai positif bagi Indonesia dengan 
penghargaan yang diraih pada kegiatan internasional tersebut sebagai upaya dalam memperkenalkan pariwisata halal Indonesia, terutama bagi negara sebagai target pasar wisata di Timur Tengah.

\section{b. Increasing Positives Appreciation dengan Pemenuhan Fasilitas dan}

\section{Layanan Wisata Halal}

Dalam memperlihatkan tampilan yang baik untuk menarik kunjungan wisata sangat diperlukan, maka dari itu Pemerintah Nusa Tenggara Barat sebagai destinasi wisata halal Indonesia melakukan pemenuhan dalam hal layanan dan fasilitas yang dapat memudahkan wisatawan Muslim dalam melakukan kegiatan wisatanya. Pemenuhan tersebut diantaranya tempat ibadah, produk dengan jaminan halal, hotel syariah, dan paket perjalanan wisata halal. Nusa Tenggara Barat sendiri memiliki payung hukum dalam menjalankan mengembangkan wisata halal, yaitu Peraturan Daerah Nusa Tenggar Barat No. 2 Tahun 2016 Tentang Pariwisata Halal.

Tempat ibadah seperti masjid atau musholla di NTB dapat dikatakan mudah untuk menemukannya baik itu di pusat perbelanjaan atau masjid di sekitar tempat wisata, klaim "Pulau Seribu Masjid" menjadi salah satu nilai tawar yang baik, tercatat 4.500 masjid tersebar di 598 desa (Baskoro, 2014). Produk halal di NTB dalam memenuhi unsur wisata halal dilakukan sertifikasi oleh Lembaga Pengkajian Pangan, Obat-Obatan, Kosmetik - Majelis Ulama Indonesia (LPPOM-MUI) sudah memberikan sertifikasi halal kepada restoran hotel, restoran non-hotel, rumah makan, produk Usaha Kecil Mikro dan Menengah (UMKM). Sedangkan hotel syariah dan paket perjalanan wisata halal dikelola oleh Dinas Pariwisata Nusa Tenggara Barat, Badan Promosi Pariwisata Daerah (BPPD) Nusa Tenggara Barat, Dewan Syariah Nasional (DSN) dan Asosiasi Perusahaan Perjalanan Wisata Indonesia (ASITA).

\section{Tabel 2. Fasilitas dan Layanan Wisata Halal Nusa Tenggara Barat}

\begin{tabular}{l|l} 
Tempat Ibadah & 4.500 Masjdi di 598 Desa \\
\hline Produk & UMKM: 269; Rumah Makan: 200; Restoran Hotel: 75; Restoran \\
& Non-Hotel: 100; Total: 644
\end{tabular}




\begin{tabular}{l|l} 
Hotel Syariah & $\begin{array}{l}\text { Hotel Sheraton, Villa Senggigi, Grand Legi Hotel, Holiday Resort, } \\
\text { Hotel Santosa, Hotel Santika, Grand Madani Hotel, Lombok Plaza } \\
\text { Hotel, Hotel Savargra, Hotel Lombok Raya }\end{array}$ \\
\hline Paket Perjalanan & $\begin{array}{l}\text { Islamic Center NTB, Desa Sade, Masjid Karang Bayan, Gili Sudak, } \\
\text { Gili Nanggu, Gili Kedis, Jurang Malang, Sesaot, Benang Kelambu. }\end{array}$
\end{tabular}

Sumber: LPPOM-MUI, DSN Dinas Pariwisata NTB, BPPD NTB, ASITA

Data diolah oleh peneliti

Namun, dapat dipastikan bahwa produk, tempat makan, hotel, serta tempat-tempat wisata di Nusa Tenggara Barat mayoritas ramah terhadap wisatawan Muslim, seperti makanan dan minuman terjamin halal meskipun belum mendapatkan sertifikasi halal karena mayoritas masyarakat Nusa Tenggara Barat yang beragama Muslim, lalu hampir setiap hotel di NTB memenuhi kriteria hotel syariah yang menyediakan perlengkapan solat dan arah kiblat di setiap kamar serta menyediakan Musholla khusus, tempat-tempat wisata dan pusat perbelanjaan juga menyediakan fasilitas dan perlengkapan ibadah sebagai upaya untuk memudahkan ibadah pengunjung. Perlu diingat bahwa fasilitas dan layanan ini tidak sebatas untuk wisatawan Muslim, wisatawan non-Muslim pun dapat menikmatinya.

\section{c. Engaging dengan membuat event Internasional}

Membuat event internasional terkait wisata halal memberikan daya tarik tersendiri bagi wisatawan Muslim dalam mengenal destinasi wisata, melalui event internasional tersebut diharapkan rasa ketertarikan dan terjadi saling memahami antara wisatawan, masyarakat tentang tempat wisata itu sendiri. Upaya yang dilakukan oleh pemerintah Nusa Tenggar Barat dalam mengenalkan wisata halal yaitu dengan membuat familiarization Trip (fam trip) dengan tema: Familiarization Trip for Ambassadors of Middle East Countries: Promoting Cooperation in the Field of Trade, Tourism and Investment bersama jurnalis dan duta besar dari berbagai negara kawasan Timur Tengah, seperti Saudi Arabia, Mesir, Qatar, Oman, Libya, Irak, Bahrain, Yaman, Maroko, Tunisia. Harapannya adalah melalui kegiatan tersebut dapat dijadikan sebagai promosi ke negaranya masing-masing. Selain itu dibuat juga pada tahun 2015 yaitu World Islamic Travel Mart, serta di tahun 2016 yaitu International Halal Travel Fair. (Subarkah, 2018: 197). 


\section{d. Influencing dengan melakukan kerjasama internasional}

Kerjasama internasional dapat dilakukan terjadi dengan adanya pengaruh dari pemerintah setelah melakukan berbagai upaya diplomasi publik, karena merasa bahwa negara tersebut layak sebagai rekan dalam menjalin hubungan kerjasama. Bidang transportasi salah satu bidang yang penting dalam pariwisata untuk memudahkan akses menuju destinasi wisata. Bagi NTB sebagai destinasi wisata halal, wisatawan yang datang menggunakan transportasi udara dan laut sebagai pintu masuk. Wisatawan yang masuk ke NTB pun banyak limpahan dari Bali, Malaysia dan Singapura, karena penerbangan langsung ke Bandara Internasional Lombok (BIL) masih kurang. Maka dari itu Kementerian Pariwisata Republik Indonesia mendorong maskapai penerbangan untuk membuka penerbangan langsung ke Lombok terutama dari Timur Tengah. (Ridwan, 2016). Kementerian Perhubungan Republik Indonesia juga mulai membuka penerbangan langsung dari Asia Selatan sebagai pintu masuk untuk mengangkut wisatawan asal Timur Tengah, mulai dibuka penerbangan langsung dari Pakistan, Bangladesh, dan Timur Tengah akan dibuka mulai dari Arab Saudi mengajak maskapai Lion Air Group, seperti Batik Air mulai terbang dari Mumbai, India. (Lubis, 2017).

Penerbangan langsung dari Timur Tengah seperti maskapai Etihad, Emirates dan Qatar Airways mulai melakukan penjajakan kerjasama untuk membuka penerbangan langsung ke Lombok. Qatar Airways melalui Duta Besar Qatar Ahmed Jassim Al-Hamar menyampaikan kepada Gubernur Nusa Tenggara Barat TGH. Zainul Majdi atas ketertarikannya dalam membuka penerbangan langsung dari Qatar dan akan melakukan koordinasi dengan maskapai Qatar Airways serta Menteri Perhubungan Indonesia (Nursyamsi, 2016). Melalui kerjasama dalam bidang penerbangan diharapkan mampu memudahkan mobilisasi wisatawan yang berkunjung ke Nusa Tenggara Barat sebagai destinasi wisata halal, terutama memudahkan bagi wisatawan asal Timur Tengah yang tertarik dengan keindahan dan wisata halal yang ditawarkan.

\section{e. Dampak Wisata Halal Sebagai Alat Diplomasi Publik}

Diplomasi publik sesuai dengan tujuannya untuk meningkatkan citra positif agar publik tertarik dengan negara tersebut dalam hal ini terhadap wisatawan dianggap berhasil terlihat dari bagan 1. jumlah kunjungan wisatawan mancanegara yang 
berkunjung ke Indonesia dan terutama Nusa Tenggara Barat sebagai destinasi wisata halal mengalami peningkatan.

Bagan 1. Kunjungan Wisatawaan Muslim ke Indonesia

\section{KUNJUNGAN WISATAWAN MANCANEGARA DAN}

WISATAWAN MUSLIM KE INDONESIA

(DALAM JUTA ORANG)

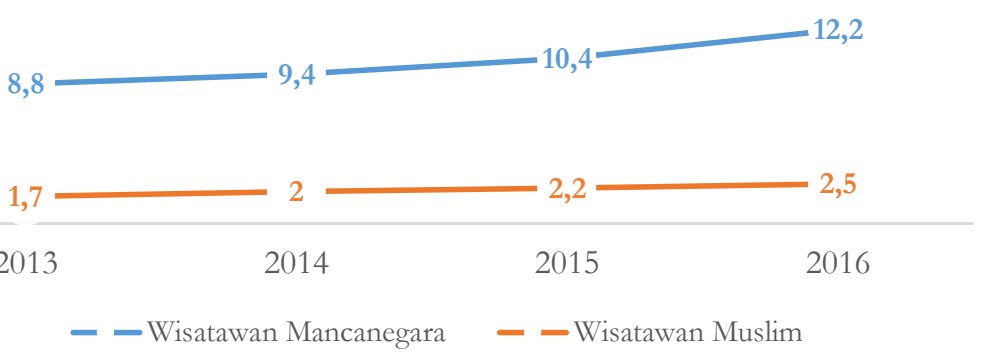

Sumber: Kementerian Pariwisata RI (diolah melalui (Garit Bira Widhasti., et. all., 2017)

Sedangkan Nusa Tenggara Barat sendiri jumlah kunjungan wisatanya juga mengalami peningkatan, berikut ini data Bagan 2. tentang kunjungan wisatawan mancanegara.

Bagan 2. Kunjungan Wisatawan ke NTB

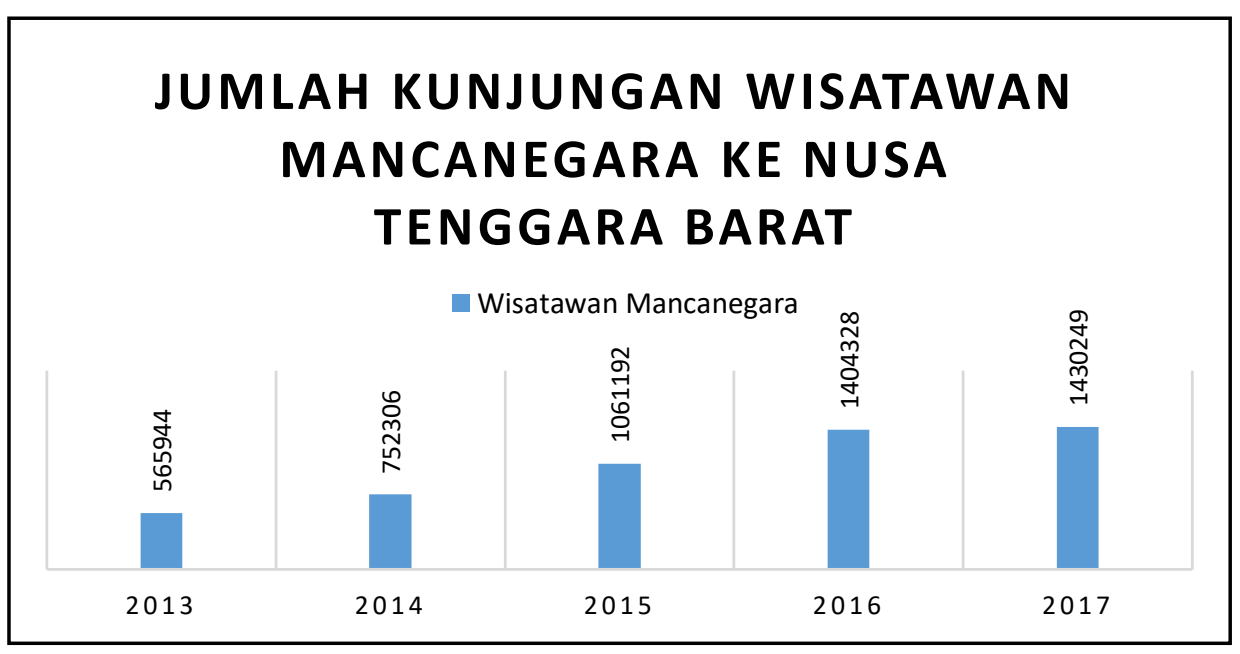

Sumber: Dinas Pariwisata Nusa Tenggara Barat (2017)

Upaya diplomasi publik Indonesia melalui pemerintah Nusa Tenggara Barat pun sudah mulai terlihat hasilnya, wisatawan asal Timur Tengah pada tahun 2014 
mencapai 405 wisatawan, naik hingga 935 wisatawan pada tahun 2016, diikuti oleh wisatawan asal Malaysia yang mencapai 502 orang pada tahun 2014, mencapai 1.719 wisatawan pada tahun 2016 dan penerbangan dari Malaysia yang biasanya didominasi oleh tenaga kerja, sekarang memiliki tren positif dipenuhi wisatawan asal Malaysia. (Asdhiana, 2016). Berbagai investor asing pun juga mulai berdatangan untuk meninjau pembangunan pariwisata yang ada di Nusa Tenggara Barat, seperti investor asal Australia berjumlah 15 orang datang meninjau beberapa titik di Kawasan Ekonomi Khusus (KEK) Mandalika dengan luas 1.200 hektar (Kelana, 2017). Selain asal Australia, tentu target utama adalah investor asal Timur Tengah, Perusahaan Maarij Capital dari Arab Saudi yang tertarik untuk berinvestasi wisata halal di NTB terutama di KEK Mandalika yang disiapkan 250 hektar untuk wisata halal. (Zuraya, 2016).

\section{Kesimpulan}

Diplomasi publik dengan introducting, increasing positive appreciation, engaging, influencing yang dilakukan oleh Indonesia melalui pembangunan wisata halal di Nusa Tenggara Barat dianggap berhasil terlihat dari kunjungan wisatawan Muslim yang mengalami peningkatan dan menarik perhatian investor asing dalam mengembangkan wisata. Jika dilakukan dengan baik dan melihat dari perkembangan wisata Indonesia, kepentingan nasional seperti meningkatkan jumlah kunjungan wisatawan pada tahun 2019 menjadi 20 juta wisatawan mancanegara akan berhasil.

Wisata halal dapat dijadikan sebagai alternatif dalam meningkatkan perekonomian daerah karena potensi pasar yang terus mengalami peningkatan, serta wisatawan millennial dengan karakteristik tersebut daerah seperti Nusa Tenggara Barat dapat melakukan memenuhi indikator dalam memenuhi kebutuhan fasilitas dan layanan bagi wisatawan Muslim, dengan target pasar utama wisatawan Timur Tengah yang menghabiskan uang untuk berwisata cukup tinggi. Namun perlu diingatkan bahwa wisata halal ini tidak hanya diperuntukkan bagi wisatawan Muslim, wisatawan non-Muslim pun dapat menikmati produk, fasilitas dan layanan wisata halal tersebut. 


\section{Daftar Rujukan}

\section{Buku}

Effendi, T. D. (2011). Diplomasi Publik Jepang Perkembangan dan Tantangan. Bogor: Ghalia Indonesia.

Leonard, M., Stead, C., \& Smewing, C. (2002). Public Diplomacy. London: The Foreign Policy Centre.

Sukadijo. (1997). Anatomi Pariwisata. Jakarta: PT Gramedia Pustaka Utama.

\section{Jurnal, Proceedings}

Aryani, S. W., Sunarti, \& Darmawan, A. (2017). Analisis Dampak Pembangunan Pariwisata Pada Aspek Ekonomi dan Sosial Budaya Masyarakat (Studi Kasus pada Desa Wisata Bejiharjo, Kecamatan Karangmojo, Kabupaten Gunungkidul D.I.Yogyakarta). Jurnal Administrasi Bisnis Vol. 49. No. 2 Agustus 2017, 142-146.

Aryunda, H. (2011). Dampak Ekonomi Pengembangan Ekowisata Kepulauan Seribu. Jurnal Perencanaan Wilayah dan Kota, Vol. 22, No. 1, April 2011, 1-16.

Ayad, N. (2012). Rethinking Strategic Public Diplomacy: the Role of Social Media. Diplomatic Academic Proceedings (pp. 23-32). Republic of Croatia: Diplomatic Academy Ministry of Foreign and European Affairs Republic of Croatia.

Battour, M., \& Ismail, M. N. (2015). Halal tourism: Concepts, practises, challenges and future. Tourism Management Perspective Volume 19, Part B, 150-154.

Effendi, T. D. (2013). Diplomasi Publik Sebagai Pendukung Hubungan IndonesiaMalaysia. Jurnal Ilmu Hubungan Internasional Universitas Parabyangan, 47-61.

Garit Bira Widhasti., et. all. (2017). Diplomasi Publik Pemerintah Republik Indonesia Melalui Pariwisata Halal. Jurnal Solidaritas: Ilmu-Imu Sosial, Volume 1, Nomor 1, Tabun 2017, 8.

Hairey, L. S. (2013). Dampak Pariwisata Terhadap Pendapatan dan Tingkat Kesejahteraan Pelaku Usaha di Kawasan Wisata Pantai Nestapa, Pulau Ambon. Jurnal Organisasi dan Manajemen Volume 9, Nomor 1, Maret 2013, 87105.

Herlambang, D. D. (2016). Dampak Pariwisata Terhadap Kondisi Sosial dan Ekonomi Penduduk Sekitar Lokasi Wisata Air Terjun Kedung Pedut di Dusun 
Kembang, Desa Jatimulyo, Kecamatan Girimulyo, Kabupaten Kulonprogo. GeoEducasia Vol. 1, No. 1, 1-19.

Indraswari, R., \& Hermawan, Y. P. (2015). Diplomasi Publik dan Nation Branding. Bandung: Lembaga Penelitian dan Pengabdian kepada Masyarakat Universitas Katolik Parahyangan.

Jaelani, A. (2017). Halal tourism industry in Indonesia: Potential and Prospect. International Review of Management and Marketing, Vol. 7 No. 3, 23-34.

Komalasari, I. (2017). Upaya Indonesia Meningkatkan Daya Saing Muslim Friendly Tourism (MFT) Diantara Negara-Negara OKI. Jurnal Ilmu Komunikasi Univeristas Riau, Vol. 4 No. 2 Oktober 2017, 1-12.

Kusumaningrum, D. N., Fairuz, A. M., Putri, E. P., \& Amalia, E. P. (2017). Trend Pariwisat Halal Korea Selatan. Seminar Nasional Gelar Produk (pp. 855-865). Malang: Universitas Muhammadiyah Malang.

Nizar, M. A. (2011). Pengaruh Pariwisata Terhadap Pertumbuhan Ekonomi Di Indonesia. Jurnal Kepariwisataan Indonesia Vol. 6, No. 2, 195-211.

Remi, S. S., Waluyo, S. D., \& Muljarijadi, B. (2016). Peran Pariwisata Dalam Perkembangan Perekonomian Daerah Studi Kasus Provinsi DKI Jakarta. Fakultas Ekonomi Universitas Padjadjaran Ikatan Sarana Ekonomi Indonesia , 122.

Subarkah, A. R. (2018). Diplomasi Pariwisata Halal Nusa Tenggara Barat. Intermestic: Journal ofInternational Studies, Volume 2, No. 2, Mei 2018(2), 188-203.

\section{Laporan}

Advisory Committee on Cultural Diplomacy U.S. Departement of State. (2015). Cultural Diplomacy The Lichpin of Public Diplomacy. U.S. Departement of State: Advisory Committee on Cultural Diplomacy U.S. Departement of State.

Deputi Bidang Ekonomi. (2014). Pembangunan Pariwisata 2015-2019. Jakarta: Kementerian Pariwisata Republik Indonesia.

Dinas Pariwisata Nusa Tenggara Barat. (2017). Kunjungan Wisataan Ke Nusa Tenggara Barat Dalam Waktu 5 Tahun Terakhir. Mataram: Dinas Pariwisata Nusa Tenggara Barat. 
Global Muslim Travel Index. (2015, 2016, 2017, 2018). Global Muslim Travel Index. Singapore: CrescentRating \& Mastercard.

Global Muslim Travel Index. (2016). Global Muslim Travel Index Report 2016. Singapore: CrescentRating.

Global Muslim Travel Index. (2018). Global Muslim Travel Index 2018. Singapore: Mastercard \& Crescentrating.

Mastercard \& HalalTrip. (2017). Muslim Millennial Travel Report 2017. Singapore: Mastercard \& HalalTrip.

Organisasi Kerjasama Islam. (2017). Strategic Roadmap For Development of Islamic Tourism in OIC Member Countries. Ankara-Turkey: Organisation of Islamic Cooperation: Statistical, Economic and Social Research, and Training Center For Islamic Countries.

Ratman, D. R. (2016). Pembangunan Destinasi Prioritas 2016-2019. Jakarta: Kementerian Pariwisata Republik Indonesia.

Turkish Asian Center For Strategic Studies. (2016). Strategic Vision Document: Tourism Diplomacy "Development of Sectoral Diplomacy". Turkey: Turkish Asian Center For Strategic Studies.

World Halal Travel Summit. (2015). Post Show Report World Halal Travel Summit 2015. Abu Dhabi: Committee World Halal Travel Summit 2015.

\section{Berita/Artikel Online}

Aprilyani, J. (2018, Maret 12). Indonesia Bidik Pasar Wisatawan Timur Tengah. Retrieved from Kontan.co.id: https://lifestyle.kontan.co.id/news/indonesia-bidikpasar-wisatawan-timur-tengah

Baskoro, D. (2014, Desember 8). Pesona Lombok Pulau Seribu Masjid. Retrieved from Okezone.com: https://lifestyle.okezone.com/read/2014/12/07/406/1075832/pesonalombok-pulau-seribu-masjid

Chandra, A. A., \& Damarjati, D. (2017, Oktober 17). Tiga Tabun Jokowi-JK, Pariwisata Sumbang Devisa Terbesar Kedua. Retrieved from Detik.Com: https:// finance.detik.com/berita-ekonomi-bisnis/d-3687715/tiga-tahunjokowi-jk-pariwisata-sumbang-devisa-terbesar-kedua 
I Made Asdhiana (ed.). (2016, September 22). Terasa Dampak Positif Wisata Halal. Retrieved from Kompas.com: https://travel.kompas.com/read/2016/09/22/170600827/terasa.dampa k.positif.wisata.halal.lombok

Indonesia.Travel. (2018, Februari 7). Indonesia Dominates World Halal Tourism Awards 2016 Winning 12 Top Categories. Retrieved from Indonesia.Travel: https://www.indonesia.travel/gb/en/news/indonesia-dominates-worldhalal-tourism-awards-2016-winning-12-top-categories

Kelana, I. (2017, April 27). Asing Minati Investasi Wisata Halal. Retrieved from Republika.co.id: https://republika.co.id/berita/kolom/fokus/17/04/27/op12ge374asing-minati-investasi-wisata-halal

Lubis, H. U. (2017, Juli 21). Menbub Ajak Maskapai Garap Rute Asia Selatan dan Timur Tengah. Retrieved from Detik.com: https://finance.detik.com/beritaekonomi-bisnis/d-3569268/menhub-ajak-maskapai-garap-rute-asiaselatan-dan-timur-tengah

Nursyamsi, M. (2016, Oktober 30). Gubernur NTB: Qatar Tertarik Buka Penerbangan Ke Lombok. Retrieved from Republika.co.id: https://www.republika.co.id/berita/nasional/daerah/17/08/09/gayahidup/wisata-halal/16/11/30/ohg4p1301-gubernur-ntb-qatar-tertarikbuka-penerbangan-ke-lombok

Pratiwi, F. (2016, April 20). GMTI Jadi Acuan Kriteria Wisata Halal. Retrieved from Republika.co.id: https://www.republika.co.id/berita/koran/financial/16/04/20/o5xd08 10-gmti-jadi-acuan-kriteria-wisata-halal

Ramli, N. (2012, Januari 26). Halal Tourism: The Untapped Market for The Halal Industry and Its Services. Retrieved from International Islamic University Malaysia: http://irep.iium.edu.my/15536/1/HALAL_TOURISM-KUWAIT.pdf

Ridwan, M. F. (2016, Februari 9). Menpar Dorong Penerbangan Langsung Timur Tengab Ke Lombok. Retrieved from Republika.co.id: https:// republika.co.id/berita/gaya- 
hidup/travelling/16/02/09/o2a1cn328-menpar-dorong-penerbanganlangsung-timur-tengah-ke-lombok

Rosana, F. C. (2018, Juni 8). Berwisata Halal di Indonesia, Ini Uang Belanja Turis Timur Tengah. from Tempo.co: https://travel.tempo.co/read/1096535/berwisata-halal-di-indonesia-iniuang-belanja-turis-timur-tengah

Sucipto, R. H. (2016, Maret 28). Wisata Topang Krisis. Retrieved from Republika.co.id: https://republika.co.id/berita/koran/teraju/16/03/28/o4qv5211wisata-topang-krisis

Susanti, I. (2017, Agustus 17). Kontribusi Pertumbuban Pariwisata di Sektor Ekonomi Terbesar dan Tercepat. Retrieved from Sindonews.com: https://ekbis.sindonews.com/read/1231216/34/kontribusipertumbuhan-pariwisata-di-sektor-ekonomi-terbesar-dan-tercepat1502940648

Zuraya, N. (2016, Oktober 22). Investor Arab Saudi Tertarik Investasi Wisata Halal di NTB. Retrieved from Republika.co.id: https://www.republika.co.id/berita/ekonomi/syariahekonomi/16/10/22/off9wf383-investor-arab-saudi-tertarik-investasiwisata-halal-di-ntb 